\title{
INFLUÊNCIA DO CALOR NA ANÁLISE DE DNA EXTRAÍDO DE SANGUE E TECIDOS HUMANOS: IMPORTÂNCIA PARA A IDENTIFICAÇÃO DO CORPOS CARBONIZADOS
}

\author{
Mara Cristina Tramujas CALABREZ
}

Calabrez, M.C.T. Influência do calor na análise de DNA extraído de sangue e tecidos humanos: mportância para a identificação de corpos carbonizados. São Paulo, 1999. 92p. Tese (doutorado) -Faculdade de Medicina da Universidade de São Paulo. Saúde, Ética \& Justiça, 4(1/2):62-4, 1999. [Resumo]

Resumo: A identificação de carbonizados leva a família da vítima a um longo e doloroso processo desde a identificação cabal do de cujo até a organização dos negócios pessoais do mesmo, para que assim a vida familiar continue. A lei brasileira requer o atestado de óbito com identificação positiva para que o cadáver seja liberado para a família. Tal documentação é também essencial à coleção de seguro de vida, o ajuste de bens, ações referentes ao morto, novos casamentos e várias outras situações encaradas pela família. O processo de identificação de vítimas carbonizadas extensivamente geralmente se inicia com a tentativa do reconhecimento pessoal, de marcas características (cicatrizes, tatuagens, sinais próprios de doença etc.), impressões digitais e/ou registros odontológicos. Entretanto, devido aos efeitos do calor e das severas lacerações sofridas, a identificação por meio médico-legal clássico não é sempre possível. Além disso, a falta de registros prévios (odontológicos ou médicos) assim como de outras características únicas (como em crianças) também pode dificultar/impedir o processo de identificação de restos humanos decorrentes da carbonização. Nestes casos, o DNA assume papel importante na identificação científica atuando como fator discriminatório decisivo ou mesmo necessário a confirmação. cabal da identificação individual. Em vítimas severamente carbonizadas as mudanças autolíticas assim como os efeitos deletérios do calor propiciam a degradação do DNA. Assim, a aplicabilidade da análise do DNA de tecidos moles através do RFLP é obviamente limitada. Atualmente, a análise de STR parece ser uma ferramenta poderosa possibilitando o trabalho com amostras forenses em baixas condições (quantidade pequena de DNA altamente degradado), onde praticamente qualquer seqüência curta de DNA pode, potencialmente, ser rápida e facilmente analisada. Entretanto chamamos atenção ao fato que a extração de

\footnotetext{
${ }^{1}$ Doutora em Ciências (Medicina Legal) pela Faculdade de Medicina da Universidade de São Paulo. Endereço para correpondência: Rua Teodoro Sampaio, 115. 05405-000. São Paulo, SP.
} 
"DNA analisável" é o principal fator limitante no processo de identificação de vítimas carbonizadas extensivamente. O objetivo desta pesquisa consiste em: 1 . determinar qual a técnica de extração de DNA, de vítimas severamente carbonizadas, melhor se presta na obtenção deste material para fins de identificação médico legal; 2 . avaliar viabilidade do sangue humano, exposto a temperaturas altas, submetidos a análise utilizando marcadores de polimórficos; 3 . avaliar quais são as principais características macroscópicas que o corpo/resto de corpo/sangue de vítimas carbonizadas, apresenta quando submetido a temperaturas altas, a fim de orientar a coleta e seleção da amostra além do procedimento de extração de DNA. Finalmente, avaliar se as vítimas que são trazidas ao Setor de Antropologia do IML/SP para identificação podem ser amostradas e identificadas através da análise do DNA. No presente estudo relatamos uma técnica alternativa de extração de DNA de corpos carbonizados vítimas de acidente aéreo e automobilístico, identificados por marcadores polimórficos; sendo o primeiro tipo STR onde três loci de tetranucleotideos são detectados simultaneamente em uma única reação de amplificação (PCR) (MultiPlex I); e o segundo do tipo VNTR (D1S80). Sangue e tecido (alguns casos) de 38 cadáveres carbonizados não identificados tiveram o DNA extraído, submetido a amplificação pela PCR, seu perfil analisado pelos marcadores acima citados, e finalmente comparados ao perfil genético (DNA) dos pais, irmãos/irmãs, maridos/ esposa e flhos, confome o caso. Através deste processotodas vím as foram ilentificadascom êxto.

Unitermos: Calor/efeitos adversos. DNA/análise. DNA/sangue. Tecidos. Cadáver. Antropologia forense.

Calabrez, M.C.T. Heat influence on DNA analysis of blood and human tissues: the importance to the identification of fire victims. São Paulo, 1999. 92p. Tese (doutorado) -Faculdade de Medicina da Universidade de São Paulo. Saúde, Ética \& Justiça, 4(1/2):62-4, 1999. [Abstract]

Abstract: The identification of human remains from fire victims entitle surviving family members to go through the grieving process; place legal, business, and personal affairs in order, and continue with the process of life. Brazilian law requires a positive identification and a formal documentation of death from the IML to release the corpse to its own relatives. Such documentation is also essential to the collection of life insurance, the settlement of estates, actions in wrongful death suits, remarriages and several others situations that have to be faced by the standing family. Fire victims identification process is generally attempted by recognizing personal effects, individualizing marks (scars, tattoos, sign of known disease etc.), fingerprints identification and/or dental records. 
However, due to effects of heat and severe lacerations of the body, the identification by usual forensic means is not always possible. Furthermore, lack of previous dental/medical records or other unique features (as may be the case with children) also may hamper the identification process of charred human remains. So the DNA results play an important role on the scientific identification of charred victims as a decisive discriminatory factor or as a needed confirmatory identification factor. In severely charred fire victims both autolytic changes as well as deleterious effects of heat will cause degradations of the DNA. Thus, the applicability of RFLP analysis of DNA from post-mortem soft tissue is obviously limited. At the present, the STR analysis seems to be a powerful tool to work with. forensic samples at low conditions (small amount of high degraded DNA). Virtually any defined short DNA sequence potentially can be analyzed easily and rapidly. However it is important to call attention to the fact that the main limitation on the DNA based identification process of fire victims is to achieve a "analyzable DNA". The aim of this research work is to find out: 1 . a satisfactory technique to extract a DNA, from samples of severely burned victims, that gives DNA able to be used in forensic identification ("analyzable DNA"); 2. the performance of human blood exposed to high temperatures and its DNA availability for polymorphic markers analysis; 3 . the main macroscopic characteristics of severely charred victims (corpse/human remains/blood) submitted to high temperatures, in order to guide the sampling and the DNA extraction procedure. In the present study we have shown an alternative technique to extract DNA from severely burned samples from aircraft, automobile accident and homicide victim, followed by PCR-based analysis, simultaneously detecting three polymorphic tetranucleotide SRT loci (MultiPlex I) and a VNTR marker (D1S80). Blood and tissue (some cases) from 38 corpses burned beyond recognition had the DNA extracted, submitted to ampification by PCR and the DNA analyzed. Finally, the DNA profile from victims were compared to the data from parents, brothers/ sisters, husband's/wife's and sons, depend;ng on the case. By this process all fire victims were identified successfully.

Keywords: Heat/adverse effects. DNA/analysis. DNA/blood. Tissues. Cadaver. Forensic anthropology. 